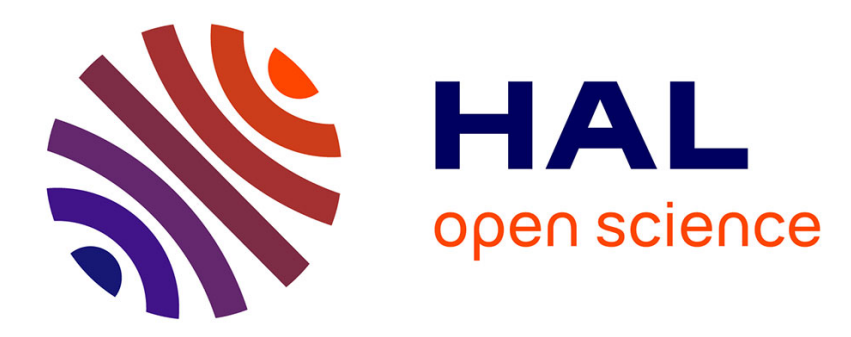

\title{
Sources of Resilience in the Computer and Software Industries in France
}

\author{
Hiroatsu Nohara, Eric Verdier
}

\section{To cite this version:}

Hiroatsu Nohara, Eric Verdier. Sources of Resilience in the Computer and Software Industries in France. Industry and Innovation, 2001, 8 (2), pp.201 - 220. 10.1080/13662710120072976 . halshs00390774

\section{HAL Id: halshs-00390774 https://shs.hal.science/halshs-00390774}

Submitted on 2 Jun 2009

HAL is a multi-disciplinary open access archive for the deposit and dissemination of scientific research documents, whether they are published or not. The documents may come from teaching and research institutions in France or abroad, or from public or private research centers.
L'archive ouverte pluridisciplinaire HAL, est destinée au dépôt et à la diffusion de documents scientifiques de niveau recherche, publiés ou non, émanant des établissements d'enseignement et de recherche français ou étrangers, des laboratoires publics ou privés. 


\title{
Sources of Resilience in the Computer and Software Industries in France
}

\author{
Hiroatsu Nohara and Eric Verdier \\ Laboratory of Labour Economics and Industrial Sociology, (LEST-CNRS), Aix- \\ Marseille University, Aix-en-Provence, France
}

Industry \& Innovation, Volume 8, Issue 2, August 2001: pages 201 - 220

\begin{abstract}
French hardware manufacturers were by and large incapable not only of translating technological advances into industrial products but even of understanding the new opportunities these advances offered. While true up to a point, this approach, focused on the failure of the so-called "national champion" policy, is incapable of explaining why French providers of IT services have had considerable success both in their own domestic market and in the wider European market. The argument advanced is that a very active higher education policy and national research strategy has produced a supply of particularly valuable competences which feed the IT sector. In addition, the previous mission-oriented policies encouraged the development of effective technological districts which now nurture the appearance of a plethora of small, innovative IT firms.
\end{abstract}


The history of the computer industry is usually divided into four main periods. The first was dominated by mainframe computers that were capable of undertaking large-scale computation tasks. The second saw the introduction of integrated circuits and the development of minicomputers. The third was characterised by the development of the personal computer, a phenomenon made possible by the invention of the microprocessor. We are now in the age of PC networks and the expansion of the "network of networks", the Internet.

Each new technological age has witnessed the emergence of new firms that have shaken the leading companies of the previous period without dislodging them from the markets in which they were previously positioned or preventing them from entering new markets (Malerba and al., 1998). The first of these leading companies was IBM. As an integrated producer of computer systems, "Big Blue" long played a dominant role and was instrumental in globalising the computer industry. The next in line was DEC, with minicomputers, followed by Apple, Commodore and Compaq as PC specialists and, above all, the beneficiaries of the "vertical disintegration" of the industry, chief among them Intel and Microsoft. "Wintelism " (Borus, Zysman 1997) led to the decline of "proprietary systems" and placed designers of "operating systems" and microprocessors in a key position, to the detriment of computer manufacturers, "Big Blue" notably, but Compaq and Toshiba as well.

This shift in market power became even more pronounced with the diffusion of the Internet. The new beneficiaries were the producers of applications (SAP, Adobe), of interfaces (Netscape) and of languages (Sun) and "pure product definition companies", such as Cisco and 3COM. The result was a move away from proprietary systems towards open systems, which ensured compatibility between the standards of the various suppliers whose products and services provide the foundations on which the networks depend. Control of these standards and of the associated intellectual property rights are essential resources for those seeking to obtain competitive advantages in these new markets in the IT industry.

These characteristics, briefly summarised here, have already been described at length by many analysts of the changes that have affected technological paradigms in the IT industry (Mowery and Rosenberg, 1998). However, this history of the industry is obviously to a large extent that of the American IT industry, since the pre-eminence of the American companies went unchallenged, with just a few exceptions. Japan was successful for a time in resisting IBM's domination by adopting the same type of mission-oriented policies as those developed in Europe, but even the Japanese finished by capitulating in the face of "Wintelism".

Moreover, the brief historical survey presented here runs the risk of making this account of IT history seem a "natural" one, the mere result of technological progress alone. In fact, this American pre-eminence induces us to examine the institutions and modes of industrial organisation that fostered this particular form of path dependency à l'américaine, in which success followed success in an uninterrupted sequence.

This acknowledgement, commonplace and trivial in itself, of the wide gap that exists between the European IT industry, particularly the French one, and its American counterpart leads us to combine this sectoral analysis with the national innovation systems approach (NIS) as developed, for example, by Freeman (1987). Freeman defines a NIS as a network of institutions operating in the public and private sectors whose activities and interactions introduce, modify and diffuse the new technologies. This approach stresses the specificity of the choices that shape the various national systems, in particular through public policies on education, academic research, legislation on patents and intellectual property and access to finance for emerging technologies.

The result is a certain dynamic irreversibility contained within "particular institutional infrastructures" (Dosi and al. 1988, Nelson, 1993, Edquist 1997). Firms draw on the 
institutional resources of their countries of origin in order to construct their competitiveness and, more generally, to operate effectively in globalised markets. The interaction between firms and these institutions gives them access to more or less effective organisational and technological learning processes through which national industries acquire their particular configuration (Lundvall 1992).

From our point of view, the case of the French IT industry provides an emblematic case of the "embeddedness" of technological and industrial development in national innovation systems. This article will attempt to explain why, at the various stages in the development of the IT industry, French hardware manufacturers were by and large incapable, despite certain flashes of inventiveness, not only of translating technological advances into industrial products but even of understanding the new opportunities those advances offered. We will focus in particular on the effects of the so-called "national champion" policy that was embodied in the Bull company and its various earlier incarnations. Over a long period, the French state maintained a policy that was commercially very protective and financially advantageous; it involved the payment of subsidies on such a scale that it became very difficult for new firms to enter the market. In the United States, on the other hand, the emergence of new competitors had long been strongly encouraged by access to venture capital; the success of this procedure was such that it became the cornerstone of current European technological policies.

Nevertheless, this interpretation is still too restrictive and the comparison with the American case is of limited heuristic value. Indeed, they both fail to take account of the positive consequences produced over the long term by sustained mission-oriented policies. In fact, these policies encouraged the development of technological districts, in Paris and in various other regions, which today, in the age of open systems, provide significant resources for the French industry as it seeks to position itself more favourably at a time when telecommunications and computing are converging.

What is more, an approach that focuses on policy failures is incapable of explaining why French providers of IT services have had considerable success in both their own domestic market and the wider European market. The argument advanced here is that a very active education policy, particularly at the higher education level, has produced a supply of particularly valuable competences. It has to be acknowledged, nevertheless, that the hardware industry also had these same resources at its disposal. However, it should be noted that the software houses were able to exploit the competitive advantage of proximity between clients and suppliers (co-production of services in the sense that Lundvall (1988) uses the term), whereas Bull was scarcely in a position to do so any longer as soon as international standards were established that overturned the positions the company had acquired on the basis of its proprietary systems. Moreover, the software houses did not have to overcome the same barriers to entry as hardware manufacturers. As a result, mobilisation of this "societal" resource produced by the education system (Maurice, Silvestre, Sellier 1986, Lanciano, Maurice, Nohara, Silvestre 1998) has until now at least produced very positive effects.

\title{
The divergent trajectories of the French computer and software industries
}

\author{
The computer industry: a long process of decline
}


Given the domination of American computer makers in the 1960s, all European countries have at some point perceived the necessity to exercise some form of interventionism in the computer industry. French policy in this area, which was introduced in the mid 1960s, has been the most systematic. Essentially a reaction to the relationship of dependency with the Americans, it was constructed upon clearly interventionist concepts, resulting in an explicit industrial policy known as the "Plan-Calcul". This typical "mission-oriented" policy was triggered by the US administration's veto of France's purchase of a large computer necessary to the development of its nuclear programme. In response, President De Gaulle's government implemented a series of measures on industrial action plans, the organisation of R\&D and the promotion of applications (Brulé 1997).

Measures under the Plan-Calcul were implemented through contracts between the public and private sectors during two periods (1966-71 and 1971-75). On an industrial level, the Plan initially staked its success on the concentration of previously disparate forces. To this end, the CII (Compagnie Internationale pour l'Informatique) was formed in 1966 from the merger of the CE and the SEA. However, in spite of state financial support, the CII did not entirely succeed in achieving the objectives set out for it. After an unsuccessful attempt to create a European alliance with Siemens and Philips under the aegis of the UNIDATA project, the company was eventually merged with Honeywell-Bull, which was of French origin but controlled by American capital.

This episode marked the end of the Plan-Calcul; the failure of the European project, followed by the transatlantic alliance, had reinforced France's technological dependency. State support for CII-HB continued, through a policy on public-sector purchasing and through a direct subsidy, until its nationalisation in 1981. Moreover, the French state attempted to relaunch the production of mini-computers through financial aid and subsidies to SEMS (a subsidiary of Thomson).

These industrial policies were accompanied by scientific and administrative measures. In 1967, the Plan-Calcul created a powerful research organisation known as the IRIA (National Institute of Computer Science), renamed INRIA in 1979. Additionally, a State agency, "General IT Delegation", was given responsibility for the promotion of IT applications. As of 1979, this role of diffusion of IT within French society was assumed by a specific entity, the "Agency for the Promotion of IT". The characteristic feature of the French case, therefore, was the creation and existence of powerful institutional "levers" facilitating state intervention in all domains of IT; the problem was that the public powers failed to coordinate these levers.

The arrival of the Socialist government in 1981 further reinforced the State's influence on the IT sector, particularly through the nationalisation of the main firms. Under the "Electronics Sector" Action Plan, finalised in 1982, the state undertook a vast programme to restructure the electronics sector around key centres of development within the public sector: Matra and Thomson in components, CGE in office applications and telecommunications, Bull in computers, Thomson in electronic consumer goods--including microcomputers--and Matra and CGE in industrial automation (Delapierre, Zimmerman 1991).

After Bull absorbed the IT subsidiaries of Thomson and CGE within the framework of the Plan, the French computer sector became organised around three main players: IBMFrance, Hewlett Packard, which had been in Grenoble since the early 1970s, and the Bull group, which became the sole "national champion". 1 Bull was able to consolidate its

\footnotetext{
${ }^{1}$ Amongst them, IBM France, with two production sites (main servers and semiconductors), is devoted to the production function and plays no active role at the strategic level. By contrast, Hewlett Packard France has 2,530 employees, including both R\&D engineers and the manufacturing workers for PCs; it has succeeded in coping with the computer paradigm shift, by moving rapidly towards RISC technology, Unix open systems and the PC.
} 
technological position through alliances around the Unix norm and its commercial position through its captive market in the French public administration. In 1987, Bull even embarked on the path of multinationalisation by buying the IT division of Honeywell, its former American owner, which had supplied it with technological knowledge before nationalisation. However, this expansion was hit by the global IT recession at the beginning of the 1990s. Bull suffered disproportionately because it remained a general producer centred on mainframe systems and neglected the rise of micro-computers. The 1990 take-over of an American specialist in this area, Zenith Data Systems, came too late to save Bull from a "historical" demise. Moreover, all French attempts to launch micro-computers ended in failure, in spite of high technological quality: Thomson Micro, Matra and Goupil all disappeared in this period of crisis. After experiencing large financial deficits, a restructuring through downsizing, and recapitalisation by the State--which incurred the wrath of the European Commission--Bull was partially privatised in 1995. The sole national actor, Bull now aims at being an integrator of technologies, progressively abandoning its own production of computers in favour of external supplies from its associates: Motorola or Intel for microprocessors, NEC for certain mainframes and IBM for Unix servers.

\section{Software industry: competitive edge despite an uncertain future}

While hardware providers have been weakened, the French software sector still shows a degree of competitiveness and can count on a certain degree of success. Indeed, the French IT industry displays a high supply capacity in the area of IT services and consultancy (Table I). Although marginalised in the production of computers and involved only in certain areas of software packages, France keeps a good performance in software services based around system integration and the development of applications. ${ }^{2}$ Its relative success, at least at European level, stems from the historical fact that the major players in this field took a key position in the implementation of IT system within the firms.

Table 1 Main players in software and IT services, 1997

\begin{tabular}{|c|c|c|c|c|c|}
\hline $\begin{array}{l}\text { IT service specialists } \\
\text { in Europe }\end{array}$ & $\begin{array}{l}\text { Turnover } \\
\text { (millions } \\
\text { francs) }\end{array}$ & of & $\begin{array}{l}\text { World-wide } \\
\text { editors }\end{array}$ & software & $\begin{array}{l}\text { Turnover } \\
\text { (millions of francs) }\end{array}$ \\
\hline IBM (US) & & 35.6 & IBM (US) & & 69.3 \\
\hline EDS (US) & & 21.3 & Microsoft (US) & & 51.5 \\
\hline Cap Gemini (Fr) & & 16.7 & Fujitsu $(\mathrm{J})$ & & 24.4 \\
\hline $\begin{array}{l}\text { Andersen Consulting } \\
\text { (US) }\end{array}$ & & 13.3 & $\begin{array}{l}\text { Computer } \\
\text { (US) }\end{array}$ & Associates & 15.8 \\
\hline Siemens-NI (G) & & 12.9 & Oracle (US) & & 12.5 \\
\hline Debis S.H. (G) & & 10.4 & $\operatorname{NEC}(\mathrm{J})$ & & 11.9 \\
\hline Computer Sciences (US) & & 9.4 & $\operatorname{SAP}(G)$ & & 9.2 \\
\hline Sema Group (Fr/GB) & & 9.3 & $\operatorname{Hitachi}(\mathrm{J})$ & & 6.9 \\
\hline $\operatorname{Bull}(\mathrm{F})$ & & 9.2 & Novell (US) & & 6.3 \\
\hline Atos $(F)$ & & 8.6 & Digital (US) & & 6.3 \\
\hline
\end{tabular}

Source: Pierre Audoin Conseil

Software and computer services firms have from the outset assumed the role of "consultants/strategists" in IT integration within the firms as much as that of software

\footnotetext{
${ }^{2}$ The French software industry is characterised by the great importance of IT services. Thus, there is a contrast between France, where services are dominant, and Germany, which clearly favours software packages and creates software editors such as SAP or Software AG etc.
} 
application technicians in the narrow sense of the term, and which means that they thus occupy a strategic position in the installation of IT systems. This positioning of software and computer services firms within the IT industry as a whole is inseparable from the historical context. At the moment that the "Plan-Calcul" was put into place, all IT producers were American, apart from the newly launched CII. Yet it was politically unthinkable to entrust American multinationals with the realisation of important works of IT engineering in the areas of defence, aerospace, telecommunications or finance. It was therefore necessary to create a national intermediary between the French administration and American manufacturers: the first software and computer services firms, such as Sema, Cap Gemini or CGI, seized this opportunity, and many such French IT service companies, at least in the beginning, worked with a public client, a situation which both accounted for the majority of their turnover and also contributed to improving the quality of their technical expertise.

In the 1980s, the considerable extension of application fields and the growing complexity of user needs generated a demand for IT solutions and software packages. A great number of new operators appeared in the software and applications sectors. On the one hand, large firms rapidly began to create subsidiary companies out of their own IT divisions. In particular, all the large banks hived off their IT divisions, thus creating large IT service companies. At the same time, the large electronics companies (CGE, Thomson, France Télécom, CEA, etc.) created networks of IT service subsidiaries. On the other hand, a breeding ground was created for new independent service companies, particularly during the 1980s, with the rapid diffusion of micro-computers. In spite of a high failure rate, these small firms displayed dynamism and a capacity for adaptation. Even if they were sometimes termed temporary work agencies, hiring out IT personnel on a daily basis, a good number of such firms developed a more professional orientation, acquiring the know-how to offer "IT service packages".

New "cutting-edge" software firms, created by the expansion of public-sector research centres, were also established in high-technology areas such as artificial intelligence, software tools, and so forth As we will see later, INRIA (National Institute of Computer Science), for example, has created forty-nine research-based start-ups ${ }^{3}$ since the beginning of the $1980 \mathrm{~s}$; these start-ups are run either by directly exploiting INRIA licences or prototypes, or by industrialising products in association with INRIA's own researchers. With this extremely diverse collection of IT service firms, France was able to build a level of IT competences which maintained its capacity for adaptation to an information society at a high level.

Nevertheless, the French software industry was faced with a more difficult domestic and international competitive environment from the beginning of the 1990s onwards. Paralleling the global IT recession, this sector stagnated for the first time in its history. This crisis thus revealed a certain lack of compatibility between supply and cost structures of a number of French IT service companies, as well as the inadequacy of their industrial and marketing processes and even a failure to globalise their activities. The IT services sector thus embarked on a process of industrial restructuring based on increased concentration and mergers (such as that between Sligos and Axime, creating Atos, the second largest IT service company behind Cap Gemini Sogeti) or take-overs (such as IBM's absorption of CGI and Axone). Apart from this search for economies of scale, another factor contributing to the restructuring of this industry was the entry of new types of companies: IT producers, telecommunications companies, software package editors, auditors and consultants. In particular, computer manufacturers themselves have played a considerable role in the changed environment: their interest in this sector derives both from a concern for keeping current

\footnotetext{
${ }^{3}$ INRIA is at the origin of 49 start-up companies, 36 of which are still actives under their own name and 13 of which have merged with other companies or stopped their activity
} 
clients and from the margins available in the service sector, which contrast with diminishing returns on hardware. IBM and Bull have thus become major actors in the French IT services sector.

This restructuring process seems linked to profound organisational changes within firms: some of these companies, which were until recently quasi-artisanal service firms, have entered a more industrial phase of production, necessitating both a standardisation of services and a formalisation of competences and investment procedures. These firms thus use strict methods of service development and build a common base of standardised products and services, offering catalogues with published tariffs, hence implying a promise of results. This more standardised type of production demands more solid financial foundations and a more rigorous selection of investment choices. These changes have gone hand in hand with greater specialisation and a considerable degree of internationalisation, since these are the only strategies which allow the imperative of return to investments to be achieved (Mowery 1996).

\section{The diverging dynamics of the hardware and software sectors}

As we have seen, although closely interwoven, the trajectories of the computer industry and the IT service industry have diverged in their paths of development. The former encountered a number of setbacks, while the latter managed to forge the international competitiveness in the period of paradigm shift. Possible explanations for this situation include the following:

The "national champion" policy adopted for the computer industry was intended to concentrate limited resources on a single targeted firm. Such a monopolistic policy could thus be said to have hampered the entry of new firms capable of bringing new ideas or technologies into the sector, even if it did not completely eliminate it. Some companies were set up, but most of them ended in failure: the newly established firms were frequently absorbed by the "national champion"--on the initiative of the public authorities--with the aim of creating a "giant" able to compete with American multinationals. This phenomenon diminished the creative dynamic that should have led to the emergence of innovative industrial systems. No matter how desirable this policy was in political terms, it was impossible in the software sector, where the market is characterised by variety, segmentation and geographical dispersion. This sector, and in particular IT services, remains a competitive market, allowing revitalisation through the continual arrival of new start-ups.

Bull, the sole "national champion", still has its core competence in proprietary system architecture and a captive clientele that accounts for the greater part of its activities. This means that Bull was, at least until the mid-1990s, a vertically integrated firm, engaged in all aspects of the production and marketing process, from microprocessor design to product sales. As the computer paradigm was shifting from closed to open systems in the 1980s, Bull had to operate radical changes in the organisational, technological and competitive domains. There were three factors which prevented it from making radical changes: strategically, Bull's national mission meant that the firm had to maintain a mainframe construction capacity in the national interest; institutionally, frequent government interventions based on political interests--because of Bull's State-owned status--impeded the maintaining of a constant orientation of organisational innovation; cognitively, Bull's bureaucratic organisation, reinforced by the appointment of public-sector technocrats ("state engineers") as senior managers, was incapable of grasping the new technological trends. Such constraints did not exist for software firms, which were able to promote their own strategies whilst benefiting enormously from government orders or semi-public markets. Moreover, IT service firms remained open to new approaches or new solutions, not only because of their proximity to 
customers' needs, but also through the high mobility of their engineers. Finally, IT service firms were able to master a new approach to the management of creativity based on less hierarchical organization.

In a sense, it might be said that such a divergence between the two sectors is the result of a "natural choice" of specialisation imposed by global competition. From our point of view, it shows also that such a choice is closely linked to the comparative advantages that the French economy has been able to derive from it specific national institutional arrangements. The national institutional frameworks in which firms are embedded are not neutral in this selection process. In this respect, the IT services sector is much better placed than the hardware sector to take advantage of resources produced by French institutions such as higher education, public research or technological districts. In the next section, we will take a closer look at the reality of interaction between the IT industry and the institutional environment in France.

\section{Institutional Creation of Resources for the French IT Industry}

The aim of this section is to examine concretely how the French system of innovation produces both professional actors and cognitive resources for the IT industry through its higher education system and public research programmes. Our main thesis is that the way in which these resources are generated cannot be dissociated from the French IT industry's structure or its strategic behaviour. In other words, there is a strong interdependence between the formation of resources and industrial capability, and the difference in sectoral performances results from the degree of strategic fitness within such interdependence (Sorge 1991).

\section{The Higher Education System as a Producer of Human Resources}

Since the middle of the 1980s, the French higher education system has succeeded in increasing significantly the supply of IT professionals. It has proved capable, in co-operation with firms, of diversifying the IT training offered. The entire French economy has thus benefited from the production of increasingly well-trained IT professionals ${ }^{4}$ In particular, software and IT service companies are able to attract a significant share of young engineers from the elite grandes écoles which select and train the best talent on the basis of mathematics and physics. This is an important factor in explaining the strength of French software and IT service companies. At the same time, however, it probably reflects the lower status of manufacturing industry in French society.

\section{IT professions in the French economy}

According to the INSEE employment survey (1997) the total number of IT professional workers (engineers and programmers) is around 281,000. This figure can be broken down into 94,800 in software and IT services companies, 10,800 in computer manufacturers, 61,500 by users in the manufacturing sector, and 113,900 by users in the service sector. Computer manufacturers thus employ relatively few of these workers (only 3.9

\footnotetext{
4 A recent OECD report put the estimated shortages of IT professionals at 75,000 in Germany, 80,000 in the UK and 400,000 in the USA and a further 25,000 in France. It could be said that with a strong emphasis on mathematics in its education system, France has a certain comparative advantage in terms of the production of human resources for the IT industry (OECD/STI 2000).
} 
$\%$ in 1997): whilst such companies remain the largest employers of IT professionals within the manufacturing sector, their relative share has continuously diminished in the 1990s, whilst increasing numbers of such workers can be found in industries such as aeronautics or automobiles. By contrast, 40 percent of all IT workers are employed by service-sector users, including 10.3 percent in commerce, 6.4 percent in financial institutions and 6.8 percent in telecommunications. Naturally, however, software and IT services companies are the biggest employers, accounting for around a third of the total. Compared with other countries, France is characterised by the large number of IT professional workers in software services companies, or in other words, by the very importance of externalisation of software jobs. ${ }^{5}$

\section{schools}

Structure of the supply of computer professionals: the dominance of the engineering

The training of computer professionals in France clearly improved from the middle of the 1980s onwards. Thus, the annual flow of newly qualified computer scientists from the higher education system increased from 4,200 in 1982 to 10,200 in 1991 and reached 20,100 in 1997, which means that the annual capacity of the higher education system to produce computer engineers increased fivefold over fifteen years. There has also been a dramatic increase in the number of students achieving qualifications at the Bac+4 standard or higher, a group which the different areas of the IT sector require as a priority. The comparison with the UK and Germany shows the very importance of such efforts: in 1996, the UK trained only 6,000 computer scientists and 4,600 electronics engineers, 70 percent of whom had three years of university education. In the same year, Germany produced 6,600 IT graduates, half in universities (6 years or more) and 11,700 electronics engineers, 40 percent of whom were trained in universities. But Germany has recently seen the number of university graduates in electronics diminish.

- The various initial training courses in computer science (hardware + software) are provided in the various tracks that make up the traditional French higher education system.

Table 2. Training Information technology in France (persons)

\begin{tabular}{|l|l|l|l|l|}
\cline { 2 - 5 } \multicolumn{1}{c|}{} & 1991 & \multicolumn{2}{c|}{1997} \\
\hline $\begin{array}{l}\text { Level of educational } \\
\text { attainment }\end{array}$ & $\begin{array}{l}\text { Annual } \\
\text { inflow }\end{array}$ & $\begin{array}{l}\text { Annual } \\
\text { inflow } \\
\text { of study }\end{array}$ & $\begin{array}{l}\text { Continuation rate } \\
\text { Balance (Entry } \\
\text { into the labour } \\
\text { market) }\end{array}$ \\
\hline $\begin{array}{l}\text { IUT administrative software course } \\
\text { BAC+2) }\end{array}$ & 33800 & 2800 & $60-65 \%(1750)$ & 1050 \\
$\begin{array}{l}\text { IUT industrial software course } \\
\text { BAC+2) }\end{array}$ & 2500 & $45-50 \%(1200)$ & 1300 \\
\hline $\begin{array}{l}\text { BTS administrative software } \\
\text { course(BAC+2) }\end{array}$ & 2000 & 2300 & $40-50 \%(1000)$ & 1300 \\
\hline First degree(BAC+3) & 1500 & 1700 & $70-80 \%(1300)$ & 400 \\
\hline Master's BAC+4) & 1250 & 1400 & $45-50 \%(650)$ & 750 \\
\hline IUP/Miage (BAC+4/5) & 800 & 1200 & $40-50 \%(550)$ & 650 \\
\hline DEA (BAC+5) & 1050 & 1300 & $25-30 \%(350)$ & 950 \\
\hline DESS(BAC+5) & 1300 & 1600 & $5 \%(100)$ & 1500 \\
\hline
\end{tabular}

\footnotetext{
${ }^{5}$ McKinsey reports that external software jobs represent $61 \%$ of the total in France (relative to internal jobs), while they account for $52 \%$ in Germany and $49 \%$ in the United States (McKinsey report 1997)
} 


\begin{tabular}{|l|l|l|l|l|}
\hline $\mathrm{PhD}(\mathrm{BAC}+8)$ & 400 & 400 & - & 400 \\
\hline $\begin{array}{l}\text { Engineering schools with } \\
\text { specialisation in computer science }\end{array}$ & 2100 & 2400 & $5 \%(100)$ & 2300 \\
$\begin{array}{l}\text { Engineering schools without } \\
\text { specialisation in computer science }\end{array}$ & & 2200 & $2 \%(50)$ & 2150 \\
\hline \multicolumn{2}{|l|}{} & 2500 & - & 2500 \\
\hline Total & & 15250 \\
\hline
\end{tabular}

Source : Syntec-Informatique

Note: the number of years' education after the BAC (Baccalaureate) corresponds to the level of exit from the higher education system.

The first track consists of short courses at the Bac+2 level (DUT or BTS). Such qualifications are considered vocational and directly focused on the labour market; they attract numerous students who are seeking a rapid entry to the labour market. The Bac+2 diploma qualifies students as programmers or IT technicians but limits them to a certain range of jobs; although it does not prevent them from reaching higher status jobs in the course of their careers, it does tend to restrict them to the technical tasks of programming or maintenance and makes progress beyond the lowest ranks of management difficult.

The second track consists of the longer university courses required to qualify for professions at all levels of the IT industry. This track, which accounts for one third of total annual flows of computer specialists, includes several pathways that have different aims.

- The first of these pathways is the most traditional, with diplomas ranging from degrees in IT to doctorates, via masters' degrees and the DEA (post-graduate diploma). This route, culminating in around four hundred doctoral theses per year, has the function of creating a reserve of IT researchers, for both higher education and publicly funded research. France has a significant intellectual force of more than 3000 IT researchers in different public organisations such as the CNRS (National Centre for Scientific Research), INRIA and CEA (Centre for Nuclear Research), and 4300 professors/lecturer-researchers in universities.

- After a master's degree, it is also possible to follow a more vocational programme of study, the DESS (one-year postgraduate diploma in an applied subject), which affords direct access to managerial status. This $\mathrm{Bac}+5$ diploma is a relatively recent development, often jointly organised by universities and firms. The fact that these programmes are designed in association with practitioners gives them a reputation for meeting the needs of firms. The third track is the engineering schools, the grandes écoles, which constitute the French elite model par excellence. Unlike the university system that is open to all those who have obtained the baccalauréat, these schools set the entrance examinations and select a small number of students. France has 200 such institutions, producing a total of 24,000 graduate engineers per year. While all the grandes écoles offer IT training, only around thirty are generally considered to be "IT schools". The ability to recruit highly qualified engineers is one of the strengths of the French IT industry, particularly in the service sector. The large software and computer services companies alone attract between a quarter and a third of newly qualified engineers $(6,000-8,000$ out of 24,000), depending on the state of the labour market. Such firms tend to recruit engineering graduates regardless of specialisation and tend to offer a further three to six months' training depending on the type of programming languages used by the company. 


\section{$R \& D$ levels in the IT industry}

The IT manufacturing industry (comprised of 70 computer and office equipment manufacturers) spends 3.35 billion francs on $R \& D$, or 4.7 percent of the turnover of the sector, and employs 3,258 researchers, which represents 9.7 percent of its workforce. The 526 firms in the software and IT service industry spend 2.92 billion francs per year, or 9.9 percent of turnover, on R\&D; 10 percent of the workforce, some 3,801 employees, are researchers. The IT manufacturing industry and the software and IT service industry account for 2.5 and 2.1 percent, respectively, of total national R\&D expenditure, and 4.9 and 5.7 percent, respectively, of the total number of researchers employed (Table III).

Table 3 Characteristics of R/D activities in IT industry: 1995

\begin{tabular}{|c|c|c|c|}
\hline & $\begin{array}{l}\text { Computer } \\
\text { industry }\end{array}$ & $\begin{array}{l}\text { software } \\
\text { industry }\end{array}$ & $\begin{array}{l}\text { All sectors (private } \\
\text { sector) }\end{array}$ \\
\hline $\begin{array}{c}\text { Number of firms } \\
\text { concerned by R/D }\end{array}$ & 70 & 526 & 4684 \\
\hline $\begin{array}{c}\text { Total number of } \\
\text { employees }\end{array}$ & 33662 & 37208 & 2533286 \\
\hline $\begin{array}{c}\text { Turnover (in millions } \\
\text { of French francs) }\end{array}$ & 71896 & 29488 & 2762531 \\
\hline $\begin{array}{c}\text { Number of R/D } \\
\text { researchers/engineers }\end{array}$ & 3258 & 3801 & 66618 \\
\hline $\begin{array}{c}\text { Total expenditure of } \\
\text { R/Dillions of French } \\
\text { francs) }\end{array}$ & 3353 & 2916 & 136443 \\
\hline $\begin{array}{c}\text { Of which public } \\
\text { financing }\end{array}$ & 595 & 124 & 15396 \\
\hline R/D Domains & $(100 \%)$ & $(100 \%)$ & $(100 \%)$ \\
\hline Basic Research & $0.4 \%$ & $0.5 \%$ & $4.2 \%$ \\
\hline Applied Research & $8.0 \%$ & $15.8 \%$ & $25.5 \%$ \\
\hline Development & $91.6 \%$ & $83.7 \%$ & $70.3 \%$ \\
\hline Sor : & & & \\
\hline
\end{tabular}

Source : Ministry of Technology and Research: Research and Development, Results 1995.

In fact, research expenditure in the IT manufacturing sector is not particularly high in relation to national averages. The 4.7 percent of turnover spent on R\&D is slightly below the national manufacturing industry average of 4.9 percent and is well behind that in the aerospace, pharmaceutical or automobile industries. ${ }^{6}$ This is so in spite of significant contributions from the State, which contributes 595 million francs out of a total of 3.35 billion francs of such expenditure, or 17.7 percent. Part of R\&D expenditure tends to be externalised or sub-contracted, with 13 percent of expenditure taking place outside the firms themselves, probably in the form of contracts with the higher education sector or public-sector research organisations. Also, the level of R\&D expenditure has stagnated in the last decade, signalling a downward trend in R\&D investment: the proportion of turnover spent on research fell from 5.7 percent in 1986 to 4.7 percent in 1995. This lack of dynamism reflects both the decline of French producers, particularly Bull, and the fact that R\&D activity has been displaced both upstream (to semiconductors) and downstream (to software).

\footnotetext{
${ }^{6}$ This R\&D expenditure in France is much lower (17-30 \%) than in Germany and UK: Source: STAN 1994 (OECD).
} 
Meanwhile, the IT service sector has increasingly become a major consumer of R\&D activities. After being largely absent from the domain of R\&D in the 1970s and 1980s, this sector has made a considerable breakthrough in this area since the end of the 1980s. The increased importance of R\&D activities is due to several factors. First, European projects such as Eureka and Esprit, in which several French software and IT service companies have been active participants (e.g. the "Software Factory"), have revealed the importance of R\&D in this sector. Second, computer manufacturers have gradually become service companies and have devoted more of their R\&D capacity to software. Finally, software and IT service companies have tended, as we have already seen, to concentrate on producing software packages and to industrialise their products, which has led to an increase in development activities.

\section{Training of the key actors in innovation}

More generally, it is important to emphasise the social and professional role of these "graduate engineers" in France. Compared with the Anglo-Saxon countries and Japan, where the engineer status is not controlled at all, the French state organises the training of engineers, evaluates the engineering schools and controls access to qualified engineer status. The engineering degree awarded by these schools gives these graduate engineers a social and professional legitimacy that immediately grants them access to the position of cadre or manager, which is regarded as an integral part of company management. Protected by law and recognised by the collective agreement, the emblematic figure of the graduate engineer in France is highly legitimated (Lanciano, Nohara et Verdier 1998).

The French education system deliberately sets out to create a very high level of educational and professional stratification linked to the qualifications pyramid. This multilayered system is based not only on the varying lengths of time required to obtain the different qualifications but also on institutional duality, such as that created by the distinction between the universities and the grandes écoles. Thus the major engineering schools, elitist institutions at the top of the academic hierarchy, provide instruction based on academic disciplines and mathematics-based training and produce engineers who are technically "generalists", even though the schools themselves specialise to a greater or lesser extent in certain technological fields (telecommunications, aeronautics, civil engineering, etc.). The most academically able graduates of these grandes écoles gravitate towards the state bureaucracy (i.e., the various branches of the civil service), which is engaged not only in industrial policy but also in largescale scientific programmes.

This situation produces close links with industrial firms, which are often managed by graduate engineers. Such close links, cemented by the mobility of graduate engineers between the public and private sectors, tend to promote the "mission-oriented" technology policy, which is a strong state-led action, rather than the "diffusion-oriented" policy backed up by intermediate organisations such as local governments, professional associations and so on (Callon and Foray 1997). The "mission-oriented" policy can result in massive failure (PlanCalcul or the Machine Tool Plan) as a result of excessive bureaucratic intervention, but also in occasional successes or even a far-reaching scientific "prowess", particularly when the state acts as co-ordinator. This phenomenon is noticeable in certain sectors such as the nuclear, aerospace and telecommunications industries, where the technocracy composed of "state engineers" co-ordinates and supports a "major national project" (Ziegler 1997). ${ }^{7}$

\footnotetext{
${ }^{7}$ This author provides an in-depth analysis of the way that differences in the forms of socialisation of engineers between France and Germany create the divergences on public industrial policy in the two countries. The existence of "state
} 


\section{Higher education and $R \& D$ institutions as cognitive resources for innovation}

The IT industry is based on a range of so-called "generic" technologies, namely materials technologies, signal processing, telecommunications and transmission technologies. The design and development of all IT products is based on these technologies and applied mathematics. Thus, the entire industry is dependent on a shared reservoir of technological knowledge.

This technological basis does not, however, form a homogenous discipline. Rather, it is constituted through the association of a multiplicity of different forms of knowledge produced in a number of disciplines. Thus, $R \& D$ activities depend on bringing together competences and knowledge that have developed relatively independently of each other. New products are often created by linking pre-existing technologies (Nelson and Winter 1982). Here, innovation mainly consists of combining already known elements in an original way, thus creating new applications in new areas.

Historically, France has tended to develop large-scale scientific programmes managed by the state in various technological spheres. As we indicated above, the state-led scientific programmes are profoundly shaped by the way in which the state technocracy is composed of engineers employed by the various branches of the civil service. The development of what we might term "technological districts" also bears the mark of this history, to the extent that they have often been constructed through the establishment of public research institutes, engineering schools and public-sector companies in specific locations. As far as IT is concerned, the Plan-Calcul and the development programme for the electronics industry have played an important role in the emergence of technological districts which continue to act as a catalyst for co-operation between industry and research: at certain sites, close collaboration takes place between higher education, public research institutions and companies. However, the logic of a large-scale, state-led scientific programme has been shown to have financial, political and strategic limits. While remaining located in local high-tech areas, IT firms have been forced to strengthen and, above all, reconfigure their collaborative networks beyond national frontiers.

\section{Development of local co-operative relationships between industry and research}

Given the importance of the French state's role in the promotion of electronic and information technologies, the development of co-operation between industry and research cannot be examined without taking into account public policies, which have been characterised by the pursuit of "technological excellence", often in the name of national sovereignty. As the case of the Plan-Calcul illustrates, major scientific and industrial programmes have been implemented by public establishments with a large degree of financial autonomy. Centralisation of technological innovation has gone hand in hand with a preoccupation with national and regional development, which has led the State to intervene by making financial contributions to regional economic development and installing scientific and technical infrastructures. As far as the IT industry in particular is concerned, the Plan-Calcul and the various national programmes designed to boost the electronics industry have contributed to the development of certain regional technological centres, first of all through the choices made in the location of public-sector research establishments (CNRS, INRIA, etc.), second, through the expansion of the engineering schools and finally through the

engineers" in France and their absence in Germany seem to explain the "mission-oriented" policy in the former case and the "diffusion-oriented" policy in the latter case. 
establishment of research facilities by public and private companies with high scientific potential (CEA, the atomic agency, CNET - in telecommunications etc.). This has led to the development of an infrastructure on which local co-operative networks can be based, although the precise form of development has differed from one centre to another. The system of cooperation between industry and research in the French IT industry thus remains largely modelled on a past policy of large-scale scientific programmes. It may be noted that the Esprit series of European programmes had no effect on existing co-operative networks and did not replace them with new arrangements. Naturally, the Esprit projects in which Bull and Thomson, as well as many software and IT service companies and research institutions such as INRIA and university teams, were active participants, allowed research networks to be extended on a European scale and brought the various players in the European IT industry closer together. From the French perspective, however, the constitution of European networks has taken place within existing local and co-operative arrangements, notably those focused around regional centres. Being established in a locality does not, therefore, seem to conflict with the extension of co-operation between the industry, universities and public research to the European scale.

Apart from the Greater Paris region (Ile-de-France), which accounts for half the national $\mathrm{R} \& \mathrm{D}$ capacity, there are four other dynamic regional centres for electronic technologies with a high IT component. ${ }^{8}$

Grenoble region: By far the most important centre outside Paris is the Grenoble region. Often dubbed the French "Silicon Valley", this area occupies first place in the European league table for micro-electronic research. In particular, the semi-conductor industry benefits from synergies based on a close link between research and production. This region accounts for 10 percent of national expenditure on R\&D in electronics and it employs 600 researchers, 1,900 engineers and 500 designers of integrated circuits in semiconductor industry (Usine nouvelle 1997). The region has a strong university tradition, which acts as a catalyst for co-operation between public-sector research establishments and engineering schools and companies, including both large groups (Bull, Hewlett-Packard, Thomson, CapGemini etc.) and small and medium-sized firms such as Soitec (start-up from CEA), which commercialises the silicon surface treatment technology, Jay Electronique, which is engaged in optoelectronics, Robobat, which produces software packages for structural calculation and Polyspace (an INRIA spin-off), which develops software validation tools.

Toulouse: The second centre is constituted around Motorola and IT firms linked to the aerospace/space industry in the Toulouse region. This concentration was explicitly created through national policies in aerospace, space sciences and electronics, namely the decentralisation of the CNES (National Centre for Space Science), the location of AirbusIndustrie and the arrival of Motorola within the framework of the Plan-Calcul. This is the location of one of Motorola's semi-conductor production plants, as well as a research centre in power integrated circuits which it runs in conjunction with the CNRS. In addition, the aeronautic and space industries are both major consumers of electronic technologies and attract industrial electronics companies such as Thomson and Matra Datasystems, as well as sustaining numerous software companies. This productive infrastructure is fed by flows of engineers trained by engineering schools such as the Ecole Nationale Supérieure de l'Aéronautique as well as scientific universities.

\footnotetext{
${ }^{8}$ In terms of scientific/technological activities (academic publications and patents application), Paris is ranked as the most active region in Europe, Grenoble at 31st place and Toulouse at 56th place. Source,: Science and Technology 2000, OST.
} 
Brittany: The third centre, in the Brittany region, is organised around digital telecommunications technology (IT, telecommunications and networks). This region has several engineering schools and universities specialising in telecommunications (Ecole Nationale Supérieure de Télécommunication etc.), from which 600 engineers, 950 higherlevel technicians and $250 \mathrm{Bac}+5$ level university students graduate annually. This area attracts numerous small and medium-sized high-technology enterprises (Ipsis, Sacet in mobile telephony, Cr2a-di, Odaxys in network architecture and Ystel.com or Isocèle in multimedia products/services etc.) and large corporations such as Alcatel, ATT, Matra, Canon and Thomson multimedia, as well as 4,000 researchers in public-sector institutions such as CNET (National Centre of Telecommunications Research) and INRIA. In all, 40 percent of French research in telecommunications is concentrated in the Brittany region.

Sophia-Antipolis: The fourth centre, Sophia-Antipolis, in the Nice region, was one of the first prototypes of the now-familiar science park (Longhi 1999). Built in a region with no industrial tradition in the 1970s, its aim, from the outset, was to bring together R\&D activities by encouraging strategic partnerships between public research laboratories and corporate laboratories. It is currently home to 1100 firms of which $25 \%$ belong to the IT sector, mostly small and medium-sized technological or research firms, employing more than 2,000 IT engineers and researchers. Although this centre is not exclusively devoted to electronic activities, the sector is well represented by public establishments such as the Ecole de Mines, University of Nice and CNRS, INRIA labs with 1400 students in computer science or telecommunication, as well as research centres belonging to multinational groups such as Nortel networks, SAP, Lucent technologies, or Compaq. This district is also characterised by the presence of academic spin-offs from the public institutions. In the 1980s, for example, INRIA-Sophia set up some of the first spin-offs, such as Simulog or Ilog in the fields of computer modelling and continues to establish small high-technology companies such as Istar in the field of digital mapping databases, Realviz in computer vision, Focus Imaging in computer-aided medical analysis, Activanet in internet services and so on.

\section{R\&D co-operation in the Grenoble region}

If all the various aspects of its intellectual activities are taken into account--the number of researchers employed, the concentration of higher education institutions and research laboratories, and the number of innovative firms--Grenoble can very properly be described as a "technological district" in the generally accepted sense of the term (Bernardy de Sigoyer and Boisgontier 1988, Salais and Storper 1997).

This region has a long tradition of co-operation between industry and higher education in innovation networks, which emerged in the electrical engineering industry in the 1930s. The exchange of know-how and local synergies was maintained in the electro-chemical industry until the advent of the micro-electronic industry in the 1970s. It is undeniable that the Grenoble region had already hosted co-operation between local productive actors which would justify the title of "technological district", or local innovation system. It was against this background that IT emerged from the 1970s onwards, and the infrastructure was renewed around a few dominant establishments such as CNET, LETI (Laboratory of Microelectronics) and Thomson-CSF in the area of semi-conductors, and INRIA, Bull, Hewlett-Packard and XEROX in the IT sphere. At the same time, a large number of small high-tech companies were created, principally as a result of the decentralisation of research centres. 
The Grenoble region therefore constitutes an interesting case of an IT industrial district. For our purposes, however, we will try to describe, by way of illustration, the institutional landscape in Grenoble, and its multiple networks of co-operation between industry and higher education.

With regard to higher education, the region has a scientific university and the INPG (National Polytechnic Institute of Grenoble), which is a public federation of nine engineering schools, over thirty research institutes and a doctoral programme. This federal structure accommodates a total of three thousand engineering science students, producing some three hundred doctoral theses per year. In particular, ENSIMAG (Higher National School of IT and Applied Mathematics), a pioneer in IT education, plays a central role in the specialised education of computer scientists (500 students), with symbiotic links between education and research involving the IMAG (Grenoble Institute of IT and Applied Maths) institution. With regard to IT research, there are seven research institutes situated on the university campus under the IMAG label and jointly administered by the CNRS, INPG and the Scientific University of Grenoble. IMAG combines the functions of scientific research, teaching in the engineering school and university and the supervision of doctoral students. Its seven institutes vary in size, containing between thirty and one hundred staff members; each brings together several teams working on concrete topics such as multimedia systems, real-time programming, parallel calculation, computer assisted translation, and so on. The federal structure allows teams to share resources (IT resources, media library, management, etc.), to participate in decision making and to deal more effectively with external partners. Most of these institutes work at the interface between theoretical and applied fields, and have contacts not only with other public research establishments (CNET, INRIA) and foreign universities, but also with firms. With these different partners, they are capable of developing co-operative networks over time. Collaboration with enterprises ranges from sub-contracting to the joint development of software packages and supervision of doctoral theses (through jointly funded scholarships), and so on.

With regard to public-sector research, INRIA has a research institute in Grenoble with some 230 people. INRIA, one of the smallest public research institutions with 715 permanent posts $^{9}$, is charged with the tasks of developing a centre of scientific excellence in the area of IT, identifying future IT needs and rapidly diffusing its scientific results in partnership with companies. To these ends, it has five research establishments across France, and a budget (in 1997) of 495 billion francs, of which 81 billion, or around a sixth, consist of 360 contracts with external partners. These are predominantly industrial contracts with companies $(40 \%)$ and European contracts in the Esprit framework (one-third). It has a workforce of some 2,100 people, of which 1,700 are scientists (715 permanent posts, 550 doctoral students/researchers, 650 foreign visitors, and 400 external collaborators from industry or higher education). Unlike the other public research institutions, it has historically supported the policy of academic spinoffs; in 2000, thirty-six start-ups generated a combined turnover of 800 billion francs and had 1400 employees, either by directly exploiting INRIA licences or prototypes, or by industrialising products in association with INRIA's own researchers. Additionally, the institution has just created a subsidiary, "INRIA-Transfert", a consultancy which aims to support the foundation of new IT companies and also "I-Source", which is the first venture capital fund dedicated to IT start-ups.

The Grenoble institute has 230 researchers, of which around 100 are doctoral students working on the joint projects with the IMAG Institute mentioned above. In 1997, the Institute was working on nine projects, mostly with external partners, in the following areas:

\footnotetext{
${ }^{9}$ Compared with CNRS (26200 permanent posts), CEA (atomic agency; 11500 permanent posts), CNET (4500 permanent posts) etc., INRIA is the smallest public laboratory among the French scientific institutions.
} 
- Communications IT (networks, Internet, systems and applications). Projects in this area involve a significant degree of partnership with firms such as Bull, Rank Xerox, SGSThomson, Aerospatiale, Hewlett-Packard, and others.

- Intelligent machines (digital imaging, intelligent vehicles). These involve strong collaborative relationships with EDF (Electricité de France), Renault, CNET, and others.

- Parallel calculation (basic software and intensive calculation). These involve partnerships with software and IT service companies such as Simulog and Matra Cap Systèmes.

Despite all these projects, the Institute has only 70 of its own researchers, who work with around 100 doctoral researchers and around 60 outside partners. It is thus heavily dependent on external resources supplied by the local infrastructure. It co-operates strongly with Bull (which has a research centre in Grenoble) in a "grouping of economic interest" which jointly manages four programmes. Through this relationship, the Institute is permanent host to around ten Bull engineers. This partnership is, in great part, the inheritance of longestablished collaboration between Bull's scientific department and the local scientific community (particularly IMAG). INRIA has increasingly become the main catalyst in the process of turning scientific findings into concrete applications.

This brief outline of the situation in Grenoble should only be seen as an illustration and has no pretensions to being representative at the national level. However, it provides us with deep insights into certain aspects of the dynamic of innovation in France.

\section{Concluding remarks}

Firms' competitiveness does not depend solely on their strategies and actions. It is fundamentally related to the quality of the societal space of which they are a part, which brings into play industrial policies, academic-industrial research links and the quality of higher education. From this point of view, the strength of the American IT industry does not seem to rest simply on the innovative capacity of its large firms such as IBM, Sun Microsystem or Intel. Indeed, its power seems to rely more on the dynamic engendered by new entrants than the well-established big firms. New firms are constantly being created to undertake innovative projects; they rely on the mobility of engineers (spin-offs) and often takes advantage of the opportunities offered by venture capital funds. This start-up dynamic, based on capacities for innovation and collective learning, seems to be an essential engine in the transformation of the IT industry in the US (Saxenian 1998).

Given the overwhelming force of the American IT industry, including in terms of software packages and IT services, Europe certainly seems to suffer from structural deficiencies inherited from past "national champion" policies (Paulré 1997). Despite these weaknesses, some European countries seem to be showing their capacity to resist the American offensive, drawing on knowledge, competences or positions linked to their own institutional set-ups. In particular, the case of France, which in the past systematically developed state policies in favour of IT, shows us how actors in the innovation process rely on existing institutions to revitalise their innovation activities.

The French IT industry, like those of most other European countries, has come under intense technological competition from the US. The industry's supply structure is dominated by the presence of American firms within France, both in the production of computers and the editing of software packages. French strengths can be found in IT services based around system integration and the development of applications. Indeed, French software houses are managing to resist the American pressure not only with their captive market (an important public sector), but also with their quality of service based on cognitive and local proximity to 
their clients. They are thus able to accumulate specific competences linked to their particular environments: for example, certain French software houses excel in scientific calculation or production of state-of-the-art software, because of their proximity to the aerospace and nuclear industries. Moreover, as in the majority of knowledge-intensive services, the user-producer relationship is of fundamental importance in the IT sector, since the development of software requires a sort of co-production between computer engineers and clients. This is a prime example of a sector where the clients intervene directly in the production of services, hence the importance of the quality of interaction between producers and users, emphasised by Lundvall (1988). In this way, the competences accumulated in the sector of application services seem to reflect the structure of the national economy, or more precisely, the international specialisation of a country. From this point of view, the proximity between IT services and telecommunications network, a sector protected by the state until recently in all European countries, may create important opportunities to promote local development synergy.

The French IT industry is supported by two institutional arrangements established during the period of "mission-oriented policies", which are now universally criticised by technical and scientific experts as a political error. Paradoxically, these arrangements contribute to the production of the most important intangible resources for the IT sector, even if its contribution to the industrial success is difficult to estimate in quantitative terms. One of the resources of these IT firms would seem to be the quality of engineer training. The sector is highly dependent upon the quality of its human resources, as is the case with the majority of services based on high-level technical knowledge. Indeed, the French higher education system has been able to increase its supply of computer engineers without compromising the quality of its training. Although it is far from satisfying all demands, particularly with regard to continuing training, it has proved capable, in co-operation with firms, of diversifying the training offered. The entire French economy has thus benefited from the production of increasingly well-trained IT professionals.

But what is most evident is that French computer engineering services firms cream off a significant share of newly qualified engineers from the grandes écoles, who constitute the most socially legitimated supply of human resources. The mutual attraction established between these firms and the "best engineers" is certainly one of the strengths of the French IT services sector.

In addition to the supply of high-level human resources, a not insignificant part of the IT sector benefits from the diffuse effects, integrated into an innovative "milieu" (Gaffard 1990), of the major scientific programmes that France has historically developed. The development of "technological districts" also bears the mark of this history, to the extent that they have often been constructed through the establishment of public research institutes, engineering schools and public-sector companies in specific locations. As far as IT is concerned, several local technological districts constitute high-level centres for electronics and IT and continue to act as catalysts in promoting co-operation between industry and research. At certain sites, close collaboration takes place between higher education, public research institutions and companies, in order to create potential new resources and knowledge. In contrast to the US, however, these French districts do not fully succeed in stimulating the mobility of researchers between public sectors and firms or the launching of start-ups -except in the rare case of INRIA-, probably because of several societal elements such as the protected status of public researchers or university professors ${ }^{10}$, a scarcity of venture capital or a lack of entrepreneurship. The new French legislation on innovation,

\footnotetext{
${ }^{10}$ They gain tenure at an earlier stage of their academic careers - in their late twenties or early thirties - if they pass the competitive examination.
} 
promulgated in 1999, may well help to promote a new entrepreneurial spirit by eliminating such societal inertia.

\section{Bibliography}

Bernardy de Sigoyer, M. and Boisgontier, P. (1988), Grains de Technopole, Micro-entreprises Grenobloises et nouveaux espaces productifs, Grenoble: Presse Universitaire de Grenoble.

Borrus, M. and Zysman, J. (1997), "Globalisation with borders: The rise of Wintelism as the future of global competition", Industry and Innovation, 4 (2).

Brulé, J-P. (1993), L'informatique malade de l'Etat, Paris: Les Belles Lettres.

Callon, M. and Foray, D. (1997), "Nouvelle économie de la science ou socio-économie de la recherche scientifique", Revue d'Economie Industrielle, $\mathrm{N}^{\circ} 79$.

Delapierre, M and Zimmermann, J-B. (1991), La globalisation de l'industrie des ordinateurs, FAST programme, vol. 11: European Commission.

Dosi, G., Freeman, C., Nelson, R., Silverberg, G. and Soete, L. (eds.) (1988), Technical Change and Economic Theory, London and New York: Pinter.

Edquist, C. (ed.)(1997), Systems of Innovation, Technologies, Institutions and Organizations, London and Washington: Pinter.

European Commission (1997), Second European Report on S/T Indicators, Luxembourg.

Freeman, C.(1987), Technology and Economic Performance: Lessons from Japan, London, Pinter Publishers.

Gaffard, J-L. (1990), Economie industrielle et de l'innovation, Paris: Dalloz.

INSEE (1994, 1995, 1996), Les entreprises des Services, Système Productif, Paris.

Lanciano, C., Maurice, M., Nohara, H. and Silvestre, J-J. (1998), Les Acteurs de l'innovation: Comparaison France-Europe-Japon, Paris: L'Harmattan.

Lanciano, C., Nohara, H. and Verdier, E. (1998), "The Societal Analysis of Engineers: Comparison between France and Japan", Paper presented at the 10th conference of socio-economics, July, 20 pp.

Longhi, C (2000), "Networks, Collective Learning and Technology Development in Innovative High Technology Regions: the Case of Sophia-Antipolis, Regional Studies, Vol.33.4, pp.333-342.

Lundvall, B-A. (1988), "Innovation as an Interactive Process: from User-Producer Interaction to the National System of Innovation", in Dosi, G., Freeman, C., Nelson, R., Silverberg, G. and Soete, L. (eds.) Technical Change and Economic Theory, London and New York: Pinter, pp. 349-369.

Lundvall, B-A.(1992), National systems of innovation, toward a theory of innovation and interactive learning, Pinter Publishers.

Malerba, F., Nelson R., Orsenigo, L., Winter, S. (1998), 'History Friendly' Models of Industry Evolution : The Computer Industry ", CESPRI, WP n ${ }^{\circ} 105$, Università Luigi Bocconi, Milano, Italy.

Maurice, M., Silvestre, J-J, Sellier F. (1986), The Social Foundations of Industrial Power: a Comparison of France and Germany, Cambridge Mass: MIT Press.

Ministère de l'éducation nationale, de la recherche et de la technologie (1997), Recherche et Développement dans les entreprises; résultats 1995, Paris.

Mowery, D. C. (ed.) (1996), The International Computer Software Industry, Oxford: Oxford University Press.

Mowery, D. C. and Rosenberg, N. (1998), Paths of Innovation: Technological change in 20th century America, Cambridge: Cambridge University Press.

Nelson, R. (1993), National Innovation Systems, Oxford University Press, New York.

Nelson, R. and Winter, S. (1982), An Evolutionary Theory of Economic Change, Cambridge, Mass.: Belknap Press of Harvard University Press.

Paulré, B. (1997), L'industrie électronique européenne: hétérogénéité et incertitudes, Paris: Ministère de l'économie, des finances et de l'industrie.

Pavitt, K. (1984), "Sectoral Patterns of Technical Change: Towards a Taxonomy and a Theory", Research Policy, 13, pp. 343-373. 
Salais, R. and Storper, M. (1997), Worlds of Production: The Action Frameworks of the Economy, Cambridge, Mass.: Harvard University Press.

Saxenian, A. (1998), Regional Advantage: Culture and Competition in Silicon Valley and Route 128, $5^{\text {th }}$ edition, Cambridge, Mass.: Harvard University Press.

Sorge A. (1991); "Strategic Fit and the Societal Effect : Interpreting Cross-national Comparisons of Technology, Organisation and Human Resources", Organisation Studies 12/2, pp.161-190.

Usine nouvelle (1997), $\mathrm{N}^{\circ}$ 2589, 3 April 1997.

Ziegler, N. J. (1997), Governing Ideas, Ithaca, N.Y.: Cornell University Press. 